О. М. Пилипенко, д.m.н., професор,

О. В. Огій, асистент

e-mail: ogiy111@ukr.net

Черкаський державний технологічний університет

б-р Шевченка, 460, Черкаси, 18006, Україна

\title{
ОБГРУНТУВАННЯ ТАРИФУ НА ПЕРЕВЕЗЕННЯ ПАСАЖИРІВ АВТОБУСНИМ ТРАНСПОРТОМ У М. ЧЕРКАСИ
}

Наведено методику розрахунку мінімальної величини тарифу на пасажирські перевезення, щзо враховує інтереси транспортних підприємств та пасажирів. Розрахунок проводиться методом економічно обтрунтованих витрат, який базується на визначенні економічно обтрунтованої величини собівартості однієї поїздки пасажира, а також враховує рентабельність підприємства-перевізника. Представлено розрахунки соціально орієнтованого тарифу на основі платоспроможності населення.

Ключові слова: міський громадський транспорт; пасажирські перевезення; тариф на перевезення; вартість проїду; рентабельність перевезень.

Постановка проблеми. В лютому 2018 р. перевізники, що обслуговують автобусні маршрути м. Черкаси звернулись до керівництва міста 3 вимогою підвищити тариф 3 4,00 до 5,00 грн., і після негативної відповіді на пару годин влаштували страйк, під час якого автобуси з'їхали 3 маршрутів. Цим було викликано транспортний колапс, і лише випуск на лінію додаткових тролейбусів КП «Черкасиелектротранс» ЧМР частково вирішив проблему.

Актуальність теми дослідження, що проводиться, визначається тим, що в умовах ринкової економіки потрібно застосування нових підходів до ціноутворення, принципів і методів побудови пасажирських тарифів, які дають змогу адаптувати державну тарифну політику у сфері пасажирського автомобільного транспорту до сучасних економічних $\mathrm{i}$ соціальних умов.

Аналіз останніх публікацій. Проведений аналіз літератури виявив, що для розрахунку тарифу на транспортні послуги можливо застосовувати три основні методи:

1) метод індексації $[1,2]$;

2) метод економічно обгрунтованих витрат [3];

3) метод соціально орієнтованого тарифy $[4,5]$.

При застосуванні методу індексаиії раніше встановлені тарифи на транспортні послуги індексуються з урахуванням прогнозного індексу споживчих цін, затвердженого в установленому порядку. При цьому зазначений прогнозний індекс застосовується регулюю- чим органом 3 урахуванням періоду регулювання.

За методом економічно обтрунтованих витрат тариф визначається шляхом ділення величини необхідної валової виручки (сума повної собівартості і прибутку пасажирських перевезень, за вирахуванням дотацій) на обсяг перевезень.

За методом соціально орієнтованого тарифу розраховується максимальний рівень тарифу. Для цього витрати на транспортні послуги (частка транспортних витрат, помножена на середньомісячний дохід) діляться на середню кількість поїздок в місяць.

Метою дослідження є виявлення особливостей формування і регулювання транспортних тарифів у м. Черкаси і по Україні в цілому.

Виклад основного матеріалу. Відповідно до чинного законодавства органи виконавчої влади не рідше одного разу в рік встановлюють граничні тарифи на перевезення пасажирів і багажу всіма видами громадського транспорту. Тарифи визначаються залежно від виду транспортного засобу. Граничний тариф формується, виходячи з економічно обгрунтованих витрат підприємств-перевізників, i припускає їх беззбиткову діяльність. За узгодженням 3 адміністрацією перевізники, що здійснюють перевезення пасажирів, мають право самостійно встановлювати вартість проїзду, систему знижок і проїзних квитків. При цьому вартість однієї поїздки не повинна перевищувати граничний рівень, затверджений місцевою владою. 
Економічно обгрунтований тариф $\left(T_{e o}\right)$ на перевезення пасажирів будь-яким видом міського громадського транспорту розраховується за формулою [6]:

$$
T_{e o}=\frac{C+\Pi p-P_{\partial}}{Q},
$$

де $C$ - експлуатаційні витрати (собівартість) по перевезенню пасажирів цим видом транспорту, грн.;

Пр - прибуток (до 15 \% від собівартості), грн.; $P_{\partial}$ - розмір дотацій на перевезення пільгових пасажирів, грн.;

$Q$ - кількість перевезених пасажирів, осіб.

Величина собівартості з розрахунку на 1 км пробігу на маршруті при перевезеннях міським автотранспортом (автобусом) розраховується за формулою [6]:

$$
C=P_{\text {on }}+B_{o n}+P_{n}+P_{\text {su }}+P_{m o}+P_{u}+A M+I B
$$

де $P_{o n}-$ витрати на оплату праці водіїв і кондукторів;

$B_{\text {on }}$ - відрахування на соціальні потреби від величини витрат на оплату праці водіїв і кондукторів;

$P_{n}-$ витрати на пальне для маршрутних автобусів [7];

$P_{м м}$ - витрати на мастильні та інші експлуатаційні матеріали для маршрутних автобусів [7];

$P_{m o}-$ витрати на технічне обслуговування i експлуатаційний ремонт маршрутних автобусів;

$P_{u}$ - витрати на знос і ремонт шин маршрутних автобусів;

$A M$ - амортизація маршрутних автобусів;

$I B$ - інші витрати по звичайних видах діяльності в сумі з непрямими витратами.

Розрахунок тарифу за цим методом ускладнений тому, що перевізники, як правило, приховують інформацію про реальний пробіг автобусів, які працюють на маршрутах (а отже, і експлуатаційні витрати, які прямо пропорційні до 1 км пробігу), та кількість перевезених пасажирів.

Для удосконалення методики розрахунку вартості проїзду на автобусному пасажирському громадському транспорті в м. Черкаси пропонується, окрім розрахунку тарифу методом економічно обтрунтованих витрат, застосувати розрахунок методом сочіально орієнтованого тарифу. Використання цього методу дасть можливість оцінити доступність тарифів, встановлених регіональною владою, для населення міста.
Для розрахунку такого тарифу в м. Черкаси необхідно:

1) визначити платоспроможність населення на послуги міського пасажирського транспорту шляхом встановлення частки транспортних витрат у середньомісячному доході жителів міста;

2) визначити середньомісячний дохід як середньозважену величину за питомою вагою розподілу жителів по доходах, тобто не враховуються ті, хто одержують дуже низькі й дуже високі доходи;

3) розрахувати максимальний рівень тарифу, перевищення якого негативно відіб'ється на соціальному становищі населення.

Соціально орієнтований тариф $\left(T_{c o}\right)$ на пасажирські перевезення розраховується за формулою [6]:

$$
T_{C O}=\frac{Д_{c p} \cdot P_{b}}{K_{n}},
$$

де $Д_{c p}-$ середньомісячний дохід, грн. [8];

$P_{6}$ - максимальна частка транспортних витрат населення на послуги міського пасажирського транспорту, \%;

$K_{n}$ - середня кількість поїздок на місяць.

Таким чином, рівень тарифу (T) на пасажирські перевезення повинен знаходитися в наступному діапазоні:

$$
T_{e o}<T<T_{c o .}
$$

Встановлення тарифу на пасажирські перевезення нижче економічно обгрунтованого не забезпечить підприємство необхідними доходами для здійснення його діяльності по перевезенню. А при встановленні рівня тарифу вище соціально орієнтованого знизиться попит на пасажирські перевезення, і це негативно позначиться на соціальному становищі населення.

Дослідження показують, що частка місячної заробітної плати, яка витрачається на проїзд у міському транспорті, в різних містах Європи коливається від 1 \% (Люксембург) до 7 \% (Лондон) (рис. 1).

Порівнюючи найменші 3 цих показників, бачимо, що найменше - до 2 \% заробітної плати - на транспорт витрачають у Франції, Італії, Австрії, Ісландії і країнах Бенілюксу. Від 2 до $3 \%$ платять у скандинавських країнах, Німеччині, Польщі, Чехії, Словаччині, Румунії, Словенії, Греції, Вірменії. Низькі показники у більшості випадків забезпечуються за рахунок дешевих місячних проїзних. 


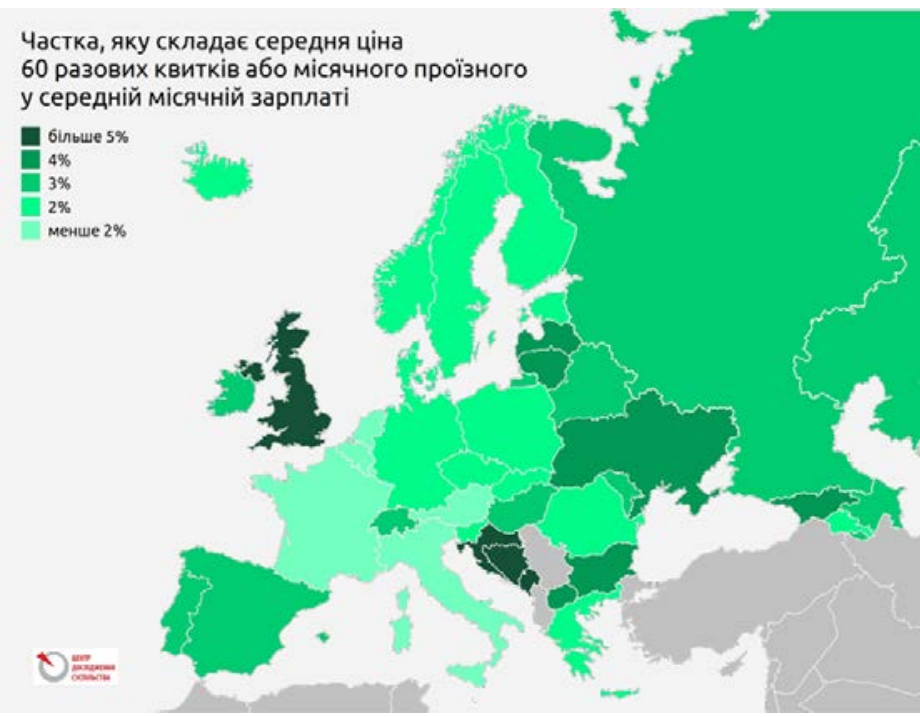

Рис. 1. Частка заробітної плати, що витрачається на проїзд у країнах Свропи

Найдорожчий проїзд - у Великобританії. У першу десятку найдорожчих входять також низка балканських країн (Боснія і Герцеговина, Македонія, Хорватія, Чорногорія), Болгарія, Латвія, Литва, Грузія, а також Україна $[9,10]$.

В Україні частка транспортних витрат на послуги міського пасажирського транспорту в середньомісячному доході населення становить приблизно $4 \%$ сумарних грошових витрат $\left(P_{\theta}=0,04\right)$.
Відповідно до мінімального набору послуг в цілому по Україні середня кількість поїздок в місяць для формування обсягу транспортних послуг визначена у розмірі $K_{n}=60$ поїздок (що передбачає дві поїздки в день).

Результати визначення соціально орієнтованого тарифу на пасажирські перевезення міським автобусом та порівняння 3 фактичним (встановленим) тарифом у м. Черкаси наведено в табл. 1, а їх графічні залежності зображено на рис. 2.

Таблиця 1

Порівняння доходу і тарифу на проїзд у міському автобусі в м. Черкаси

\begin{tabular}{|c|c|c|c|c|c|}
\hline Рік & $\begin{array}{c}\text { Середньо- } \\
\text { місячний дохід } \\
Д_{c p}, \text { грн. }\end{array}$ & $\begin{array}{c}\text { Соціально } \\
\text { орієнтований } \\
\text { тариф } T_{c o}, \text { грн. }\end{array}$ & $\begin{array}{c}\text { Діючий } \\
\text { тариф } \\
T, \text { грн. }\end{array}$ & $\begin{array}{c}\text { Різниця } \\
\text { тарифів, } \\
T_{c o}-T, \text { грн. }\end{array}$ & $\begin{array}{c}\text { Частка } \\
\text { транспортних } \\
\text { витрат } P_{b}, \%\end{array}$ \\
\hline 01.2015 & 2742 & 1,83 & 2,50 & $-0,67$ & 5,47 \\
\hline 01.2016 & 3484 & 2,32 & 3,00 & $-0,68$ & 5,17 \\
\hline 01.2017 & 5055 & 3,37 & 4,00 & $-0,63$ & 4,75 \\
\hline 01.2018 & 6418 & 4,28 & 4,00 & 0,28 & 3,74 \\
\hline
\end{tabular}

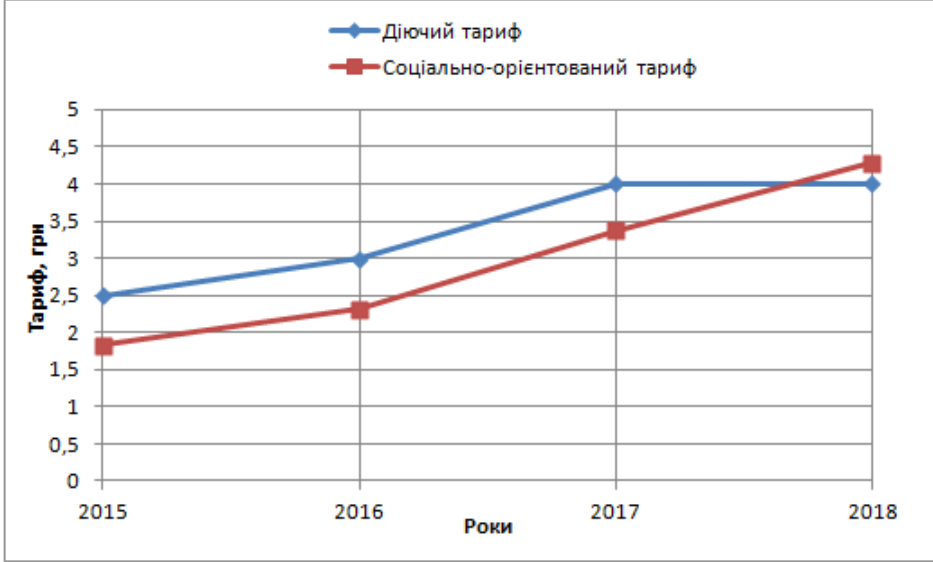

Рис. 2. Діаграма тарифів у м. Черкаси (2015 - 2018 рр.) 
3 табл. 1 та рис. 2 видно, що величина соціально орієнтованого тарифу, який показує максимальний рівень витрат населення на послуги проїзду, перевищення якого негативно відбивається на соціальному становищі населення, станом на $01.2018 \mathrm{p}$. становить 4,28 грн. при діючому тарифі в 4,00 грн., а до 01.2018 р. він взагалі щорічно завжди був меншим за діючий тариф. Якщо підняти тариф до 5,00 грн., то знову повернеться негативна тенденція, яку лише подолано.

Таким чином, у м. Черкаси рівень соціально орієнтованого тарифу на перевезення на 01.2018 р. дещо вищий, ніж встановлений місцевою владою. Однак потрібно пам'ятати, що частка заробітної плати, яка витрачається на проїзд в Україні, - одна 3 найвищих в $Є_{\text {в- }}$ ропі (рис. 1), тобто відмова місцевої влади у підвищенні тарифу продиктована прагненням знизити частку з середніх по Україні 4 до $3,74 \%$, що є хоч і мінімальним, але все одно зменшенням.

Порівняємо діючі тарифи в різних обласних центрах України (рис. 3, за [11]) із середнім доходом населення в цих містах станом на 01.2018 р. Основним критерієм порівняння вважатимемо не тариф $T$ на перевезення, а частку транспортних витрат населення $P_{6}$. 3 формули (3) отримуємо:

$$
P_{s}=\frac{K_{n} \cdot T}{Д_{c p}} .
$$

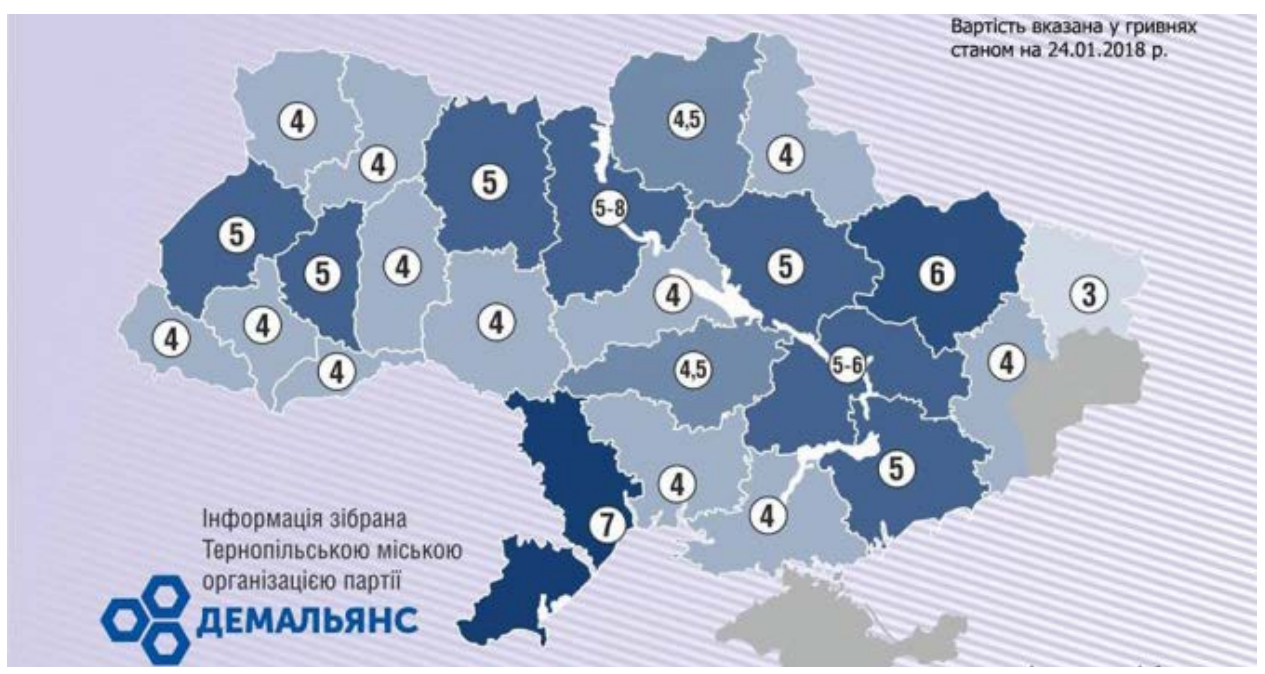

Рис. 3. Тариф на проїзд у міському автобусі в обласних центрах України [11]

Порівняння доходу і тарифу на проїзд у міському автобусі в обласних центрах України

\begin{tabular}{|c|c|c|c|c|c|}
\hline Місто & $\begin{array}{l}\text { Середньо- } \\
\text { місячний } \\
\text { дохід } \\
Д_{c p}, \text { грн. }\end{array}$ & $\begin{array}{c}\text { Соціально } \\
\text { орієнтований } \\
\text { тариф } T_{c o}, \text { грн. }\end{array}$ & $\begin{array}{l}\text { Діючий } \\
\text { тариф } \\
T, \text { грн. }\end{array}$ & $\begin{array}{c}\text { Різниця } \\
\text { тарифів, } \\
T_{c o}-T, \text { грн. }\end{array}$ & $\begin{array}{c}\text { Частка } \\
\text { транспортних } \\
\text { витрат } \\
P_{6}, \%\end{array}$ \\
\hline Миколаїв & 7067 & 4,71 & 4 & 0,71 & 3,40 \\
\hline Ужгород & 6799 & 4,53 & 4 & 0,53 & 3,53 \\
\hline Вінниця & 6750 & 4,50 & 4 & 0,50 & 3,56 \\
\hline Івано-Франківськ & 6665 & 4,44 & 4 & 0,44 & 3,60 \\
\hline Рівне & 6458 & 4,31 & 4 & 0,31 & 3,72 \\
\hline Черкаси $^{1}$ & 6418 & 4,28 & 4 & 0,28 & 3,74 \\
\hline Суми & 6400 & 4,27 & 4 & 0,27 & 3,75 \\
\hline Луцьк & 6306 & 4,20 & 4 & 0,20 & 3,81 \\
\hline Хмельницький & 6275 & 4,18 & 4 & 0,18 & 3,82 \\
\hline Херсон & 6063 & 4,04 & 4 & 0,04 & 3,96 \\
\hline Запоріжжя & 7479 & 4,99 & 5 & $-0,01$ & 4,01 \\
\hline Чернівці & 5914 & 3,94 & 4 & $-0,06$ & 4,06 \\
\hline Київ & 11668 & 7,78 & 8 & $-0,22$ & 4,11 \\
\hline Полтава & 7136 & 4,76 & 5 & $-0,24$ & 4,20 \\
\hline
\end{tabular}




\begin{tabular}{|c|c|c|c|c|c|}
\hline Місто & $\begin{array}{c}\text { Середньо- } \\
\text { місячний } \\
\text { дохід } \\
Д_{c p}, \text { грн. }\end{array}$ & $\begin{array}{c}\text { Соціально } \\
\text { орієнтований } \\
\text { тариф } T_{c o}, \text { грн. }\end{array}$ & $\begin{array}{c}\text { Діючий } \\
\text { тариф } \\
T, \text { грн. }\end{array}$ & $\begin{array}{c}\text { Різниця } \\
\text { тарифів, } \\
T_{c o}-T, \text { грн. }\end{array}$ & $\begin{array}{c}\text { Частка } \\
\text { транспортних } \\
\text { витрат } \\
P_{6}, \% \\
\end{array}$ \\
\hline Полтава & 7136 & 4,76 & 5 & $-0,24$ & 4,20 \\
\hline Львів & 6950 & 4,63 & 5 & $-0,37$ & 4,32 \\
\hline Кропивницький & 6221 & 4,15 & 4,5 & $-0,35$ & 4,34 \\
\hline Чернігів & 6098 & 4,07 & 4,5 & $-0,43$ & 4,43 \\
\hline Дніпро & 7839 & 5,23 & 6 & $-0,77$ & 4,59 \\
\hline Житомир & 6423 & 4,28 & 5 & $-0,72$ & 4,67 \\
\hline Черкаси $^{2}$ & 6418 & 4,28 & 5 & $-0,72$ & 4,67 \\
\hline Тернопіль & 5865 & 3,91 & 5 & $-1,09$ & 5,12 \\
\hline Харків & 6680 & 4,45 & 6 & $-1,55$ & 5,39 \\
\hline Одеса & 7228 & 4,82 & 7 & $-2,18$ & 5,81 \\
\hline
\end{tabular}

- тариф на проїзд 4,00 грн.

2 - тариф на проїзд 5,00 грн.

3 табл. 2 видно, що частка транспортних витрат у різних містах України має широку межу коливань, яка залежить від співвідношення тарифу на проїзд і доходу населення. Найбільша частка транспортних витрат в Одесі (5,8 \%), найменша - в Миколаєві (3,4 $\%$, а, наприклад, Київ навіть 3 тарифом у 8 грн. завдяки найвищому серед міст України середньомісячному доходу займає місце посередині рейтингу.

Підняття тарифу в м. Черкаси 34,00 до 5,00 грн. переведе місто 3 верхньої частини рейтингу в нижню, а головне - суттєво зросте частка транспортних витрат 3 нинішніх 3,74 до 4,67 \% (див. табл. 2).

Крім того, як було вже сказано вище, наведені розрахунки не стосуються найбільш незахищених верств населення, а саме тих, що мають мінімальний дохід, який у м. Черкаси на 53,6 \% менший за середній. Для них частка транспортних витрат при відсутності дешевшої тролейбусної мережі в місці проживання зросте $з$ нинішніх 8,1 до 10 \%. Навіть і проїзд на тролейбусі з тарифом у 2,00 грн. має частку транспортних витрат, що дорівнює $4 \%$.

Висновки. Станом на 03.2018 р. величина тарифу в м. Черкаси становить 4 грн., що, за розрахунками перевізників, нижче економічно обгрунтованого тарифу, тобто підприємства-перевізники працюють у збиток, що відбивається на якості транспортних послуг і безпеці перевезень.

Компромісне рішення про підняття тарифу до 5 грн. є можливим тільки після виконання основних вимог до всіх черкаських пе- ревізників: встановлення на автобусах двосторонніх відеореєстраторів, систем автоматичної фіксації порушень, систем трекінгу і нагляду за дотриманням графіків перевізниками, дотримання графіків та відхилення від них в автоматичному режимі, оголошення зупинок в автоматичному режимі, а згодом і поступове оновлення парку рухомого складу автобусами 3 двигунами екологічного стандарту не нижче Євро-4.

\section{Список літератури}

1. Бычков В. П. Экономика автотранспортного предприятия. Москва: ИНФРА-М, 2008. $384 \mathrm{c}$.

2. Гудков В. А., Миротин Л. Б., Вельможин А. В., Ширяев С. А. Пассажирские автомобильные перевозки. Москва: Горячая линия - Телеком, 2004. 448 с.

3. Герасименко В. В. Ценообразование. Москва: ИНФРА-М, 2009. 422 с.

4. Туревский И. С. Автомобильные перевозки. Москва: ИД «Форум» ИНФРА-М, 2016. 222 c.

5. Спирин И. В. Организация и управление пассажирскими автомобильными перевозками. 5-е изд., перераб. Москва: ИЦ «Академия», 2010. 400 с.

6. Никитина А. Н. Расчет оптимального уровня тарифа на пассажирские перевозки. Инженерный вестник Дона: электрон. науч. журн. 2012. № 4.

URL:http://www.ivdon.ru/magazine/archive /n4p1y2012/1112 
7. Волгин В. В. Автоперевозчик. Эксплуатационные нормативы. Москва: ООО «Издательство Астрель», 2004. 558 с.

8. https://index.minfin.com.ua/labour/salary/av erage/Черкасская (дата звернення 10.02.2018).

9. http://abcnews.com.ua/ru/discuss/sravnieniie -tsien-na-proiezd-v-obshchiestviennomtransportie-v-kiievie-i-v-50-ievropieiskikhghorodakh-1 (дата звернення 28.03.2018).

10. Автотранспорт: эксплуатащия, обслуживание, ремонт: науч.-практ. журн. / гл. ред. А. Н. Никитушкин. 2007. № 12. Тарифообразование на пассажирские перевозки.

11. https://dem-alliance.org/districts/ternopilskaoblast/district_news

\section{References}

1. Bychkov, V. P. (2008). Economy of a trucking enterprise. Moscow: INFRA-M, $384 \mathrm{p}$. [in Russian].

2. Gudkov, V. A., $\quad$ Mirotin, L. B., Velmozhyn, A. V., Shyriaev, S. A. (2004) Passenger motor transportation. Moscow: Goriachaia liniya - Telekom, 448 p. [in Russian].
3. Gerasimenko, V. V. (2009). Pricing. Moscow: INFRA-M, 422 p. [in Russian].

4. Turevskyi, I. S. (2016) Motor transportation. Moscow: ID «Forum» INFRA-M, 222 p. [in Russian].

5. Spirin, I. V. (2010) Organization and management of passenger motor transport. Moscow: Akademiya, 400 p. [in Russian].

6. Nikitina, A. N. (2012) Calculation of the optimal level of the tariff for passenger transportation. Inzhenernyi vestnik Dona: sci. e-journal, No. 4. URL: http://www.ivdon.ru/magazine/archive/n4p1y2012/1112

7. Volgin, V. V. (2004) Carrier. Operational standards. Moscow: Izdatelstvo Astrel, 558 p. [in Russian].

8. https://index.minfin.com.ua/labour/salary/av erage/Черкасская

9. http://abcnews.com.ua/ru/discuss/sravnieniie -tsien-na-proiezd-v-obshchiestviennomtransportie-v-kiievie-i-v-50-ievropieiskikhghorodakh-1

10. Avtotransport: ekspluatatsyia, obsluzhyvaniye, remont (2007) No. 12. Tariff formation for passenger transportation, pp. 41-45 [in Russian].

11. https://dem-alliance.org/districts/ternopilskaoblast/district_news

O. M. Pilipenko, Dr.Tech.Sc., professor,

O. V. Ogiy, assistant

e-mail: ogiy111@ukr.net

Cherkasy State Technological University

Shevchenko blvd, 460, Cherkasy, 18006, Ukraine

\section{SUBSTANTIATION OF RATE FOR PASSENGER TRANSPORTATION BY BUS IN CHERKASY}

The method of calculation of the minimum rate for passenger transportation taking into account the interests of transport companies and passengers is given. The calculation has been carried out using the method of economically substantiated costs, which is based on the determination of reasonable value of the price cost of one trip of a passenger, and also takes into account the profitability of the company engaged in passenger transportation. The calculation of a socially-oriented rate on the basis of effective public demand is presented.

Keywords: urban public transport; passenger transportation; transportation rate; fare; transportation effectiveness.

Стаття надійшла 27.04.2018.

Статтю представляє О. М. Пилипенко, д.т.н., професор. 